\title{
前照射アミド-無水マレイン酸系による重合
}

(昭 和 44 年 3 月 19 日受理)

田村筆・田中誠・村田二郎 ${ }^{* 1}$

\section{1 楮䇾}

電荷移動現象を重合反応に応用した研究はすでにかなり見られ る。これらの研究は大きくつぎの二つに大別される。

一つは開始剤 (ABIN など) を使用した共重合でモノマー間に 錯合体が生成し，これが生長反応に関与するるので，他方は開始 剂を使用しないで錯合体が開始ラジカルの生成に関与する場合で ある。前者に属するるのとして Garrett らうのスチレンと無水、 レイン酸間の錯合体，岩月ら 2 の $p$-ジオキセンと無水マレイン酸 の間の錯合体などがある。後者として はBawn ら ${ }^{\text {3) } の テ ト ラ ヒ ~}$ ドロフラン (THF) と無水マレイン酸 (MAH) の共存下でのメ タクリル酸メチルの光重合にお゙ける THF と MAH の錯合体, 松田 ${ }^{4)}$, Bamford $5^{5)}$ のピリジンと液体严硫酸の錯合体とハ口 ゲン化物との反応によるラジカル重合の開始などがある。著者 ら6)は THF と MAH の混合溶液に空気中, $30^{\circ} \mathrm{C}$ で紫外線を照 射したのち，この前照射溶液を開始剤とするビニル重合の開始機 構について検討した結果, THF と MAH の錯合体が生成するこ とを確認しこれを経てビニル重合を誘起する開始種が生成する ものと推定した。本報ではアミドが種々の化合物（電子受容体） と錯合体を生成することから゙，MAH を電子受容体とするアミ ド-MAH 系について検討し, 上述の THF-MAH 系の挙動との 比較を試みた。

\section{2 実験}

\section{$2 \cdot 1$ 試薬の精製および合成}

スチレン(St), メタクリル酸メチル (MMA) および $n$-ブチル ビニルエーテル (n-BVE) は常法により精製した。無水マレイン 酸 $(\mathrm{MAH})$ は市肘品を減圧蒸留して使用した。 $N, N$-ジメチルホ ルムアミド (DMF), $N, N$-ジメチルアセトアミド (DMA), 2-ピ ロリドン (PD), N-メチルー2-ピロリドン (MPD) は市眅品を窒素

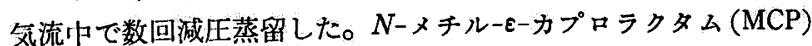
献 Benson 58) の方法で合成した。bp $118 \sim 119^{\circ} \mathrm{C} / 20 \mathrm{mmHg}$ (文 は值 $128^{\circ} \mathrm{C} / 32 \mathrm{mmHg}$ )。溶媒は常法により精製した。その他の武

*1 Hajime TAMURA, Makoto TANAKA, Niro MURATA 大阪府立大学工学部応用化学科：堺市百舌鳥梅町.

1) E. R. Garrett, R. L. Guile, J. Am. Chem. Soc., 75, 3958 (1953).

2) 和月, 山下, 工化, 67,1470 (1964).

3) C.E.H. Bawn, A. Ledwith, A. Parry, Chem. Commun., $1965,490$.

4) 松田, 平山, 工化, 70, 2022 (1967).

5) C. H. Bamford, J. W. Reynolds, J. D. Seddon, Makromol. Chem., 111, 247 (1968).

6) 田村, 阪上, 田中, 村田, 工化, 72, 304 (1969).

7）例えば, O.D. Bonner, G. B. Woolsey, Tetrahedron, 24, 3625 (1968).

8) R. E. Benson, T. L. Cairns, J. Am. Chem. Soc., 70, 2115 (1948).
薬は前報6) と同様にして精製した。

\section{$2 \cdot 2$ 活性程の生成と重合}

アミド-MAH 系に空気中, $30^{\circ} \mathrm{C}$ で 2 時間紫外線照射したのち, この溶液の一部を一定量 $(5 \mathrm{ml})$ のモノマーに加え, ドライアイ スーメタノール浴で涷結, 脱気, 溶融をくり返しのち封管とした。 これを $30^{\circ} \mathrm{C}$ に保持した恒温槽中に静置し窒素雾囲気中で 24 時 間暗重合させたのち，反応混合物を大量のメタノール中に注ぎ, えられたポリマーをグラスフィルターで口過して減圧乾燥後秤量 した。

\section{3 結果および考察}

\section{$3 \cdot 1$ 錯合体の生成}

DMF-MAH および MPD-MAH 錯合体はアミドおよび MAH の等モルクロロホルム溶液を用いて連続変化法9にによりその組成 を決定した。その結果を図 1に示す。四から明らかなように[ア ミド]/[MAH] =1/1 のところに極大值が現れることから，アミド と $\mathrm{MAH}$ との間には $1: 1$ 錯合体が生成することを確認した。

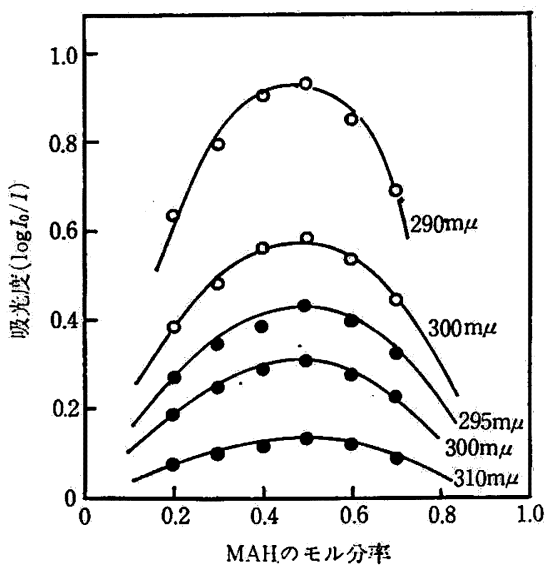

図 1 連続变化法による電子スペクトルの剆定 $0:$ MPD-MAH, $\bullet:$ DMF-MAH

$\left[\left\ulcorner\lessgtr ト^{*}\right]=0.300 \mathrm{~mol} / l,[\mathrm{MAH}]=0.300 \mathrm{~mol} / l, \mathrm{ref} .[\mathrm{M \Lambda H}]=0.300 \mathrm{~mol} / /\right.$

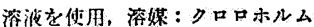

\section{3 .2 電気伝章度の測定}

MAHを DMF および MPDに溶かした溶液を空気中, 室温, 暗黒下で放置したとき，および空気中，30C で紫外線照射した ときのそれぞれの系の電気伝導度の変化を示したのが図 2 であ る。暗黑下で放置したときでも長時間経過すると系の電気伝㨍度 は增大するが，光照射を行ならと著るしく加速される。また光照 射したアミド-MAH 系の可視部の吸光度は照射時閒とともに增 大し, 電気伝導度の増加とよい対応を示すことから, 可視部に吸 收を有するイオン種（イオンラジカルも含めて）が生成している

9) P. Job, Compt. Rend., 180, 928 (1925); Ann. Chim. Phys., [10] 9, 113 (1928) ; W. C. Vosburgh, G. R. Cooper, J. Am. Chem. Soc., 63, 437 (1941). 


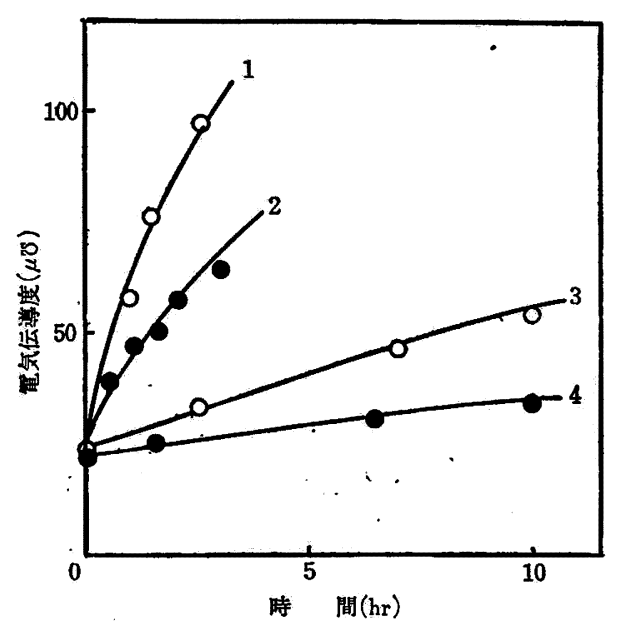

図 2 電気伝導度の経時変化

1: DMF-MAH 光照射系, 2: MPD-MAH 光照射系, 3: DMF-MAH 非然射系， $4:$ MPD-MAH 非的射系

ただし照射系は 30て，非照射系は室温にて湖定。横軸は然射系では光监射 時間を、非照射系では暗黒下での放置時間を示す。

ことを示唆する。

\section{3 前照射したアミド-MAH 系による重合}

MAH をDMF および MPD に溶かした溶液に空気中， $30^{\circ} \mathrm{C}$ で光照射を行ない，一定時間ごとにその溶液の一部をとり出して

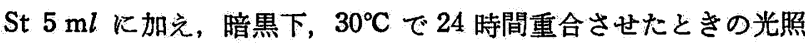
射時間と重合率の関係を表 1 に示す。図 2 および表 1 からわかる よ5に電気伝導度の照射時間による増加に比例して，重合率むほ ぼ同じ傾向で増加することから考えて，光照射により生成したイ オン種（イオンラジカルをむ含めて）が重合開始に関与するもの と推定ざれる。またアミドまたは $\mathrm{MAH}$ いずれか一成分ではほと んど重合活性を示さないことから，図1に示したアミド-MAH 錯 合体が重合の開始過程に関与するものと思れる。

表 1 光照射時間と重合率の関係

\begin{tabular}{|c|c|c|}
\hline 然射时閂(hr) & DMF-MAH & MPD-MAH \\
\hline 0 & trace & 1.35 \\
\hline 0.5 & 4.30 & 11.37 \\
\hline 1.0 & - & 11.82 \\
\hline 1.5 & 5.32 & 13.79 \\
\hline 2.0 & 6.72 & 12.88 \\
\hline
\end{tabular}

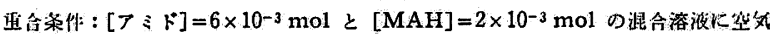

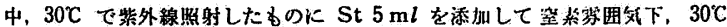
で 24 㭙間暗重合させた

一方，前照射したアミド-MAH 溶液を暗黑下，空気中（室温） で放置し，一定時間ごとにこの溶液の一部をスチレンに添加して $30^{\circ} \mathrm{C}$ で 24 時間暗重台させたときの結果を表 2 に示す。これらの 結果からわかるように，かなりの時間にわたってこの前照射溶液 の重合活性が持続することがわかる。ただし非照射つミド-MAH 采を暗黑下で放置しても電気伝導度は増加し(図 2)，重合活性を 示す。したがって，放置中に一部活性種が新しく生成しているこ とも考えられる。また種々のアミド-MAH 系を用いて,さらに St, MMA および $n$-BVE の重合を行ない，これらのモノマーに刘す る重合活性の有無, アミド-MAH 系に光照射するときの雾四效の 影響および重合系での雾囲気の影響も併せて示した。活性種生成
表 2 放置時間と重合率の関係

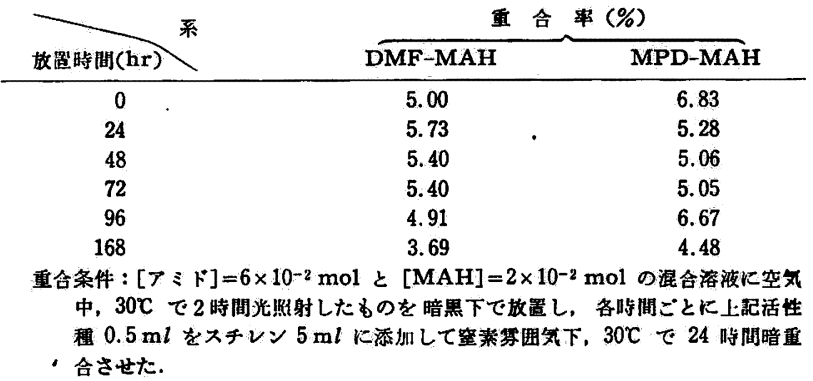

表 3 雲囲気の影響

\begin{tabular}{|c|c|c|c|c|c|}
\hline \multirow{2}{*}{ 系 } & \multirow{2}{*}{ 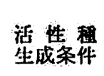 } & \multirow{2}{*}{ 重合条件 } & \multicolumn{3}{|c|}{ 重 合 } \\
\hline & & & St & MMA & $n$-BVE \\
\hline \multirow{4}{*}{ DMF-MAH } & $\mathrm{A}^{*}$ & $\mathbf{A}$ & 0.32 & 0 & - \\
\hline & A & $\mathrm{N}^{* *}$ & 6.72 & 6.53 & 1.20 \\
\hline & $\mathbf{V}^{* * *}$ & $\mathbf{N}$ & 0 & 0 & - \\
\hline & 非照射系 & $\mathbf{N}$ & trace & 0 & 0 \\
\hline \multirow{3}{*}{ DMA-MAH } & A & $\mathrm{N}$ & 6.19 & 5.96 & 0 \\
\hline & $\mathbf{v}$ & $\mathbf{N}$ & 0 & 0 & 0 \\
\hline & 非照射系 & $\mathbf{N}$ & trace & 0 & - \\
\hline \multirow{3}{*}{ PD-MAH } & A & $\mathrm{N}$ & 5.07 & 7.00 & 0 \\
\hline & $\mathbf{v}$ & $\mathbf{N}$ & 3.54 & 0 & - \\
\hline & 非业射系 & $\mathrm{N}$ & 6.33 & 0 & - \\
\hline \multirow{4}{*}{ MPD-MAH } & A & A & 0.88 & 0 & - \\
\hline & A & $\mathrm{N}$ & 12.88 & 13.20 & 0.66 \\
\hline & $\mathrm{V}$ & $\mathrm{N}$ & 2.55 & 0 & 0 \\
\hline & 非琞射系 & $\mathrm{N}$ & 1.98 & 0 & 0 \\
\hline \multirow{3}{*}{ MCP-MAH } & A & $\mathrm{N}$ & 9.47 & 6.63 & 0.51 \\
\hline & v & $\mathbf{N}$ & 1.82 & 0 & 0 \\
\hline & 非柢射系 & $\mathbf{N}$ & 1.38 & 0 & 0 \\
\hline
\end{tabular}

* 空気中，** 空素票囲気中，***真然中

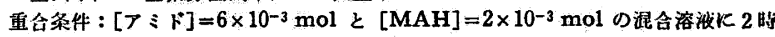

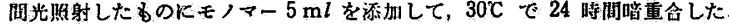

時に真空中で光照射を行なった系および非照射系での重合開始能 は St の場合は空気中で照射したときに比較して非常に小さく， MMA の場合には全く重合開始能に認められなかった。このこと は酸素が開始種生成に関与することを示唆する。著者らはすでに 前報()において前照射した THF-MAH 系でラジカル，カチオン， アニオン三様の重合開始機構を推定した。表 3 に示したごとく空 気中で重合を行なった系ではその重合率が著るしく小さいか全く 重合しない。このことから重合がラジカル機構を経て進行するこ とを示唆する。またこれらの系の $n$-BVE に対する重合開始能は 著るしく小さい。松田ら ${ }^{10)}$ はスチレンおよびその誘導体のルイス 酸によるカチオン重合が DMF 中で完全に禁止されることを報告 しており，本報でも著者らの行なった $n$-BVE の重合で重合率が 藷るしく小さいのはアミドによりカチオン重合が禁止されること によるものと推定される。さらに St および MMA の重合がジ フェニルピクリルヒドラジル，ヒドロキノン，ベンジキノンのよ うなラジカル重合禁止剤によって完全に禁止され，イオン重台に 影響をおよぼすと思われる塩化水素ガス，水およびメタノールに より，St の重合は著しく抑制され，MMA の重合はメタノール の涯加により完全に禁止される。これらの結果は重合開始種がラ ジカル，イオンの蔺作用を有することを示するのと考えられ，波 渚ら ${ }^{6)}$ がすでに報告した THF-MAH 系と類似の機满により重台 が開始されるるのと推定される。

10) N. Tokura, M. Matsuda, Y. Ogawa, J. Polymer Sci., A 1, 2965 (1963). 